\title{
The Shadow of Homeland Politics: Understanding the Evolution of the Turkish Radical Left in the Netherlands
}

L'ombre de la politique du pays d'origine : évolution de la gauche radicale turque aux Pays-Bas

La sombra de las políticas nacionales : entender la evolución de la izquierda radical turca en los Países Bajos

Liza M. Nell

\section{OpenEdition}

\section{Journals}

Electronic version

URL: https://journals.openedition.org/remi/4572

DOI: 10.4000/remi.4572

ISSN: $1777-5418$

\section{Publisher}

Université de Poitiers

\section{Printed version}

Date of publication: 1 November 2008

Number of pages: 121-145

ISBN: 978-2-911627-49-0

ISSN: 0765-0752

\section{Electronic reference}

Liza M. Nell, "The Shadow of Homeland Politics: Understanding the Evolution of the Turkish Radical Left in the Netherlands", Revue européenne des migrations internationales [Online], vol. 24 - n² 2008 Online since 01 November 2011, connection on 14 April 2022. URL: http://journals.openedition.org/ remi/4572 ; DOI: https://doi.org/10.4000/remi.4572 


\title{
The Shadow of Homeland Politics: Understanding the Evolution of the Turkish Radical Left in the Netherlands
}

\author{
Liza M. NELL*
}

Migrants' transnational loyalties and practices are the subjects of hot political debate in many European countries. Critics often worry about the influence of political transnationalism on domestic politics: do migrants 'import' foreign government influence? Does political transnationalism threaten democracy? If migrants and their descendants are actively involved in homeland politics does this signal indifference towards politics in their countries of residence? Does political transnationalism thereby hinder integration (as for example is stated by Koopmans, Statham, Giugni and Passy, 2005)?

These are big questions. They are also loaded questions, asked from the perspective of European governments. But the consequences of political transnationalism can only be understood once the phenomenon is studied transnationally - by examining causes and effects in both receiving countries and the in countries of origin.

Extant scholarship has identified a number of factors that play an important role in the evolution of transnational politics. In particular, these include political opportunities in the country of settlement and/or in the country of origin (Koopmans,

* Lecturer Cultural Anthropology and Development Sociology - Univerversity of Leiden; Fellow of the Institute for Migration and Ethnic Studies - University of Amsterdam L.M.Nell@uva.nl

I thank Rinus Penninx and Daniel Mügge for their comments on earlier versions of this paper and David Takeo Hymans for editing it. Fieldwork in Turkey from November 2004 till January 2005 was made possible through a travel grant (number R 52-1077) of the Netherlands Organisation for Scientific Research (NWO). 
Statham, Giugni and Passy, 2005; Koopmans and Statham, 2003; Ögelman, 2003; Østergaard-Nielsen, 2003); migrants' length of stay (Foner, 2001; Guarnizo, Portes and Haller, 2003; Morowska, 2003; Al-Ali, Black and Koser, 2001); and their migration motives (Østergaard-Nielsen, 2003). The scholarship has also shown that organisations often form the backbone of political transnationalism; because they channel individual activities, organisations are central in many studies (Ögelman, 2003; ØstergaardNielsen, 2003; Argun, 2003). In important ways, then, understanding organisational patterns becomes synonymous with understanding political transnationalism itself.

Organisational patterns - and the transnational activities they channel change over time. Once migrants settle permanently, some organisations disappear while new ones are formed. The political focus of migrants' organisations also shifts, often (though not always) towards issues in the country of settlement. At this most general level, many studies of transnational politics ask a deceptively simple question: what explains this variation - over time, between different migrant communities, and between different organisations and political currents?

This paper follows this line of analysis with a sharpened focus. It addresses the evolution of radical left transnational political organisations among Turkish migrants in the Netherlands. Within this political segment, trajectories have differed markedly. Many radical organisations, particularly in the late 1970s and early 1980s, were short-lived. Of the organisations that still exist, some have become more moderate; others have retained their radical edge. The focus of these radical organisations has also shifted over time: many have grown more interested in the position of their members in Dutch society than in political conditions in Turkey. This, however, is not true for all of them: a number of organisations retain their ambition to influence Turkish politics. This variation, then, forms the core empirical puzzle of this paper: what explains the different trajectories of transnationally active radical left Turkish organisations in the Netherlands?

While political opportunities, migration motives and length of stay are relevant to our case, they cannot, in themselves, explain important differences between the political trajectories of different leftwing Turkish migrant groups. For most of the groups studied in this paper, the above factors have been similar or have remained constant. For example, virtually all radical left movements were outlawed in Turkey after the coup in 1980. Many of the migrant organisations studied here were set up in similar times, under similar conditions, by people with similar migration motives. And while the political climate for left movements in Turkey has changed several times over the past decades, the effect on migrant organisations abroad should have been roughly comparable. So what explains the variation between the trajectories of these organisations?

Many migrants are not only active transnationally; they are also organised in transnational networks. Most leftwing Turkish migrant organisations maintained active contacts with their counterparts in Turkey, or with those in exile in other European countries. In many cases, organisations in the Netherlands functioned as branches of movements in Turkey. Conversely, movements operating clandestinely in Turkey had 
their operational bases abroad. As an organisation, however, the Turkish and (in this case) Dutch branches co-operated closely. Under which conditions were organisational structures in the Netherlands directed from Turkey? For organisations in the Netherlands without legal counterparts in Turkey, the opposite question arises: under which conditions were organisational structures determined by political opportunities in the Netherlands? And how did political developments in Turkey influence organisational structure? Did organisations in the Netherlands survive developments in Turkey, or did they change their goals and activities?

To answer these questions, the next section provides a broad historical sketch of left political movements since the 1960 s, focusing on those that have mattered to Turkish migrant organisations in the Netherlands. The aim here is to provide some background to a bewildering political landscape. The empirical core of the paper, which follows, is divided into three parts: the first concentrates on developments up to the fall of the Berlin wall, a watershed for the left in Turkey as well as for affiliated organisations in the Netherlands. The following two sections then focus on the period since the early 1990s, more specifically on the transnational ties of Turkish migrant organisations with (1) parties that are now legal in Turkey, and (2) with organisations that remain prohibited there.

\section{THE LEFT IN TURKEY}

When I asked for political asylum in the Netherlands in 1981 the interrogator handed me a long list of Turkish left organisations, asking me to point out the one in which I was active. The list was so long, I had never even heard of some before - and they all had exile members in the Netherlands! ${ }^{1}$

This quote is telling of the myriad Turkish left organisations and their presence in the Netherlands. The late 1960s and early 1970s was a period of intense activity for the Turkish left. Influenced by developments in Turkey, ideological differences within the international socialist movement, and internal conflicts, the 'left movement' broke into numerous splinter groups. With the arrival of refugees from Turkey, these groups came to be represented among Turks in the Netherlands. Figure 1 shows the evolution of the Turkish left since the 1960s (for the interest of clarity the table only shows groups that had or have representation in the Netherlands - these were, however, the most prominent players). See appendixes 1 and 2 for founding dates, orientations and abbreviations).

Igor Livosky (1992) has authored an excellent study on the emergence and development of radical left parties in Turkey between 1960 and 1980. It analyses the rise of complex and fragmented legal and illegal left movements in the context of changing political opportunities, in which the military coups of 1960, 1971 and 1980 were crucial. The socialist movement in Turkey was completely banned between 1950 and 1960. In 1960, in the face of acute social, economic and political crisis, a group of

1 Interview with a former Dev Yol activist in exile, Amsterdam, 6 October 2004. 


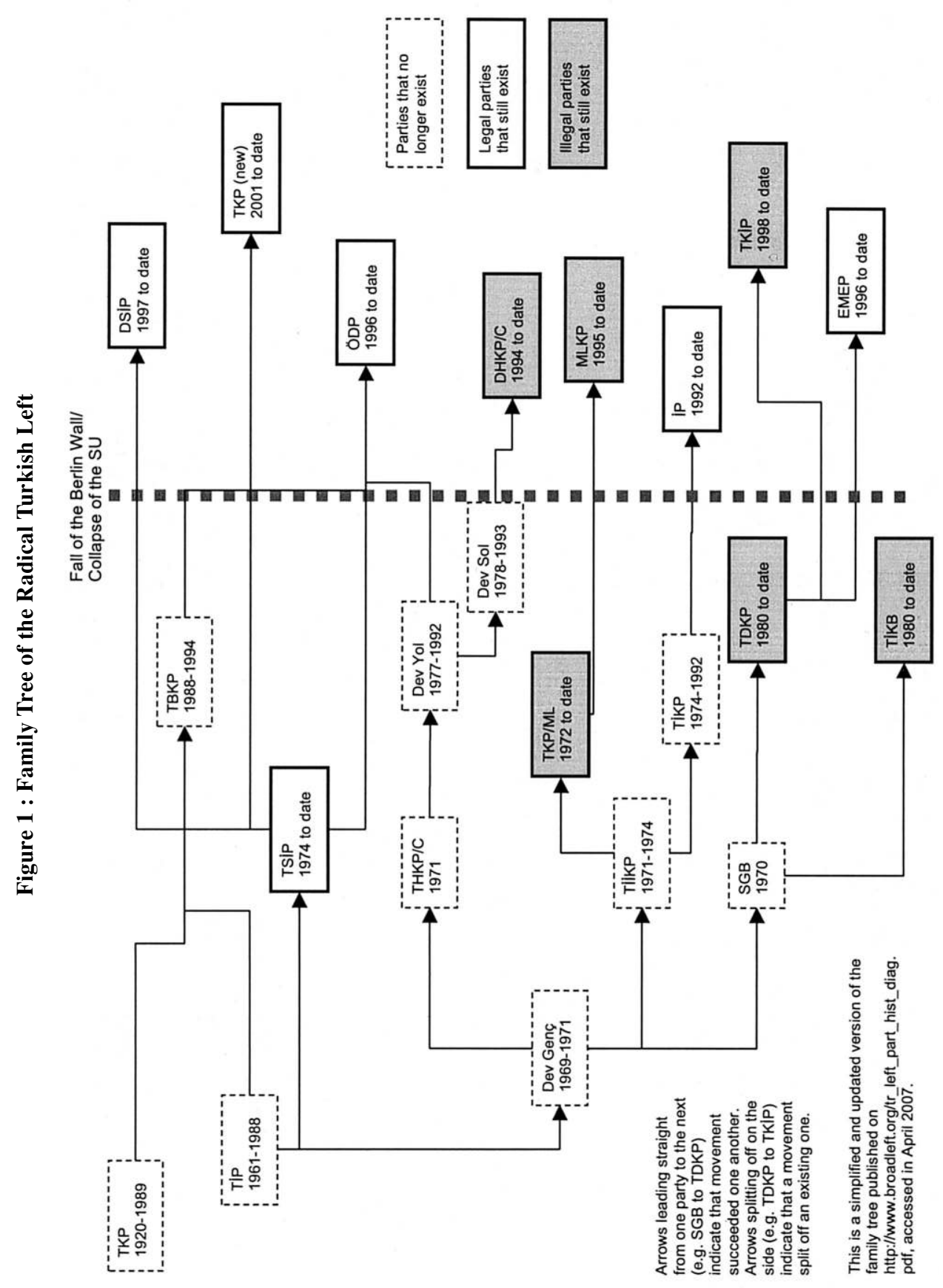


patriotic military officers overthrew the government and adopted a new democratic and liberal constitution (1961). This paved the way for the surfacing of ideological currents that had long been suppressed. A legal left movement emerged in Turkey in which diverse left-wing radicals, social democrats, trade unionists and Marxists were active, stylizing themselves and the movement as 'socialist.' Only the official communist party TKP - which had existed since the 1920s - remained prohibited and operated clandestinely (Lipovsky, 1992: 1-3).

Between 1961 and 1971 many members of the socialist movement acted through the legal Marxist workers party TIP, founded in 1961. Other non-party leftist groups set up their own organisations, which first supported but later clashed with the TiP. These groups represented a wide spectrum ranging from the left wing of the social-democratic CHP to underground Marxist organisations. The struggle between the various ideological currents and the electoral failure of the TIP in 1969 led to a crisis that split the TİP around 1971 (Lipovsky, 1992: 67-82 ; Poulton, 1997: 211). The most important product of this split was the emergence of the student confederation Dev Genç, in which many future leaders of leftwing organisations were active.

But Dev Genç was short-lived. Within two years, it had splintered into small groups of revolutionaries each with their own organisations. They proliferated under the influence of external events such as Mao's radicalism in the Cultural Revolution of the late 1960s and the student revolt in Paris of 1968 (Poulton 1997: 211). Given the political climate, the Turkish extreme left increasingly came to advocate armed struggle; their acts of terror helped plunge the country into the chaos that led to the coup of 12 March 1971 (Lipovsky 1992: 1). The declaration of martial law in major urban areas and in the provinces where Kurdish nationalists were active paralysed political life: youth organisations and meetings of professional organisations and unions were banned (see Ahmad, 1993; McDowall, 1996). New groups - both Maoist and Marxist-Leninist - appeared, with former Dev-Genç cadre dissolving into the various splinter groups.

The socialist movement flourished with the handing back of power to the political parties in 1973. Ideological, political, and personal differences among socialists, however, led to fierce struggles both within the camp and against the rising groups of nationalists, the so called Ülkücü Ocaklarl (Idealist Hearths) (Landau, 1981: 148). The Ülkücü Ocaklarl began breaking up leftist meetings to defend Turkey from 'communism' (Landau, 1974; “'nar and Arıkan, 2002), prompting responses from the revolutionary group Dev Yol and the workers and peasant party TIKKP (both with origins in the Dev Genç movement). Dev Yol organised local 'anti-fascist' resistance committees across Turkey to combat the 'imperialism' of the right. The TIKKP blasted the 'fascism' of both nationalist groups as well as the Moscow-oriented communist party TKP, whom they considered 'social fascists' (Turkije Informatie, 1978). ${ }^{2}$

2 An important party that originated in the leftist movement was the Kurdish party PKK. Since, Kurdish nationalism soon overshadowed leftist ideology of the PKK and the development of this party is a study an sich, the PKK is left out in this study. 
The struggle between left and right, however, was unequal. This was due not only to their numbers (60 000 armed militants on the left against 100000 on the right), but to the police and security forces having become the preserve of the nationalist party MHP. With the MHP in government between 1974 and 1977, and then again under Prime Minister Bülent Ecevit, the police and security forces were heavily infiltrated by MHP sympathizers. This protected the Grey Wolves, the MHP's youth movement (Landau, 1981; Zürcher, 2004:263 ; Pope and Pope, 1997: 132).

By the end of the decade, violence no longer only consisted of reciprocal killings by left and rightwing extremists. Both groups began to kill public figures, such as the deputy chairman of the MHP and a leftist trade union leader. Whole neighbourhoods came under the control of one or the other of the competing groups and were declared 'liberated areas'. With the authorities seemingly unable to restore order, and with the economy in crisis, the army returned to power on 12 September 1980 ("'nar and Arıkan, 2002: 28; Zürcher, 2004: 264).

All power was now in the hands of the military. Under a new law on political parties, politicians were banned from politics for ten years and their parties dissolved. Political leaders were arrested; parliamentarians and local administrators discharged. A state of emergency was declared throughout the country, from which no one was allowed to leave. Furthermore, anti-terrorist campaigns no longer only targeted leftist activists, but the MHP and the Grey Wolves as well. By 1982, 80000 people were imprisoned and torture was widespread (Zürcher, 2004: 278-280).

The military interventions of 1971 and 1980 heavily influenced leftist strategy. Most groups continued their activities in exile or illegally in Turkey itself. The activities of the Moscow-oriented communist party TKP, officially prohibited from the late 1960s until 1975, were mainly based outside Turkey. The party was directed from cites in socialist countries like Moscow or Prague, where TKP leaders resided (see Landau 1974: 105). Due to the increasing population of Turkish workers and refugees, Europe - and especially Germany - became the main exile base for leaders of illegal left parties in the late 1970s and 1980s.

A civilian government replaced the military after general elections in November 1983. In contrast to the previous return to civilian rule, these elections did not fully restore the political freedoms that had existed prior to the 1980 coup (Lipovsky 1992: 167). With its figureheads either in jail or in exile, the left now remained excluded from the legal political arena. While the political spectrum had broadened again by 1987 (old leaders were running political parties behind the scenes and making still officially illegal political statements), it was not until 1993 that political parties were allowed to re-open using their traditional names (Argun, 2003: 140; Güneş-Ayata, 2002: 106). In the meantime, internal divisions and ideological confusion following the fall of the Berlin wall in 1989 had reduced the ranks of the left (Østergaard-Nielsen, 2003: 49).

The early 1990s witnessed the founding of new parties, many of which had their origins in the late 1960s student movement Dev Genç. Though their memberships were small, they represented the full spectrum of ideologies that had been present in 
the 1970s. A group sympathetic to Mao and Albanian communism were organised in EMEP. A wide range of illegal radical left parties also arose, the most important of which were the Revolutionary Peoples Liberation Front, DHKP/C, and the Marxist Leninist Communist Party, MLKP (Østergaard-Nielsen 2003b: 50). Today, groups that used to follow the Moscow-oriented communists are mainly represented in the legal ÖDP.

The choice to continue politics within a legal or illegal party obviously affected strategy. Legal parties, including EMEP and ÖDP, participated in the 2002 general elections, though none passed the ten per cent threshold. Wishing to improve upon their negligible success in electoral politics, many of these parties have increasingly come to emphasise international mobilisation, for example through participation in international anti-globalisation movements such as the World Social Forum (Baykan and Lelandais, 2004: 520).

In contrast to the legal left, radical groups such as DHKP/C and the MLKP have continued the violent strategies of their forerunners and retain their armed wings. Like their predecessors, some of their leaders live in exile in Europe. Party programmes also resemble earlier ones. $\mathrm{DHKP} / \mathrm{C}$, for example, aims to organise people in Turkey into people's councils to build a mass movement (DHKC, 1998: 142) in order to beat 'fascism and state terrorism' (Kurtulus, 1997: 149-151) through 'democratic' revolution. 'If necessary the people will fight for justice' (DHKC, 1998; DHKP, 1995; DHKC, 1998). One of the most visible activities of the DHKP/C and MLKP is their support of prisoners detained for activities within their respective parties. Protesting against the suppression of a prison rebellion, DHKP/C killed a businessman in Istanbul in 1996 (Pope and Pope, 1997: 127). The non-governmental organisation TAYAD supports DHKP/C and MLKP militants by reporting on hunger strikes, cases of torture and on missing members (TAYAD Solidarity Committee, 2001). TAYAD further supported the DHKP/C and MLKP 'Death Fast Resistance' of prisoners protesting prison reforms to detain them separately (Anderson, 2004: 823). Between 2000 and 2003, more than 2000 prisoners participated in the 'Death Fast Resistance'; 107 died (Anderson 2004: 817). After intervention by the security forces to suppress the strikes in 2001, relatives and friends of the striking prisoners began solidarity death fasts in Istanbul (Kulaksiz, 2003).

\section{HOMELAND POLITICS OF EXILES AND MIGRANT WORKERS IN THE 1970S AND 1980S IN THE NETHERLANDS}

Leftwing organisations established by migrants mirrored political developments in Turkey. Emigration to Western Europe in the 1970s offered banned parties such as the TKP a liberal political climate for the mobilization of guest workers (Landau, 1974: 105; Turkije Informatie, 1978: 23). In many cases they aimed to recruit workers in Western Europe so that their movements would be strengthened once migrants returned to Turkey (for Germany see Miller, 1981). However, in the early 1980 s - paralleling the situation in Turkey - radical left politics among migrants moved out of public view and into an atmosphere pervaded by rumour and 
intimidation. Many members of the Turkish community now feared taking strong political stands and did not want to be seen as part of any one particular political group (Penninx, 1980).

The military interventions of 1971 and 1980 led to the arrival of Turkish political migrants in Europe, individuals who had been members of revolutionary organisations in Turkey and who now brought their political convictions with them (for Germany see Miller, 1981: 53-54). In contrast to the political refugees of the 1980s, refugees after the 1971 coup did not ask for asylum but arrived in the Netherlands more or less 'unnoticed' as 'guest workers' (Bakker, Vervloet and Gailly, 2002: 212). Young

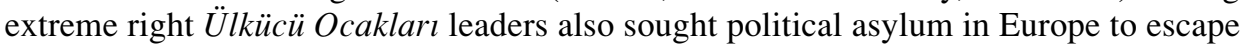
the left-right violence in the schools and universities (see also Van Esbroeck, 1979; Geerse, 1998). In this way, conflict between the left and right in Turkey was transplanted to the Netherlands.

The focus on Turkish politics among leftist migrant workers increased dramatically after the coup in 1980. Political refugees swelled their ranks. Mirroring internal and ideological divides in Turkey, a wide spectrum of radical leftist groups continued their activities in exile and mobilized workers for their party in Turkey. Each of these parties had its own network with members throughout Europe (see also Özcan 1992). In the Netherlands they organised activities against the Turkish junta separately, cooperating instead with their counterparts in Germany. They demonstrated in front of national parliaments, organised hunger strikes and shared their views of political developments in Turkey with the European public and governments through magazines and pamphlets (see for Dev Yol Turkije Informatie, 1981; for Dev Sol Turkije-Nieuws, 1981).

To illustrate these developments, the next subsections describe how political orientations were reflected by Turkish migrant organisations. Although numerous organisations were founded in this period, we focus exclusively on two organisations that exist to this day. The first, HTIBB, represented Moscow-oriented communism and was founded in response to the 1971 coup; the second, DIDF, was Maoist-oriented and a response to the coup of 1980.

\section{Moscow-oriented leftist organisations: the foundation of HTİB}

The first leftist organisation for Turkish labour migrants in the Netherlands, HTİB, was established in 1974 by a group of Turkish workers and refugees who had fled the military repression of 1971 (Can and Can-Engin, 1997: 66). With its Marxist orientation, the HTİB sympathised with the communist party of Turkey, TKP. HTİB's initial goal was to include migrant workers living in the Netherlands within the Turkish people's struggle for a democratic Turkey. At the same time, HTIB assisted Turkish migrant workers in their 'struggle' for rights in the Netherlands.

The 'struggle' in the Netherlands included activities against the establishment Turkish organisations. Paralleling developments in Turkey in the 1970s, leftwing Turkish groups in the Netherlands fought one another as well as rightwing groups 
(Turkije Informatie, 1977; Rath, 1985). In 1977 HTIB campaigned to ban from the Netherlands organisations of the Grey Wolves which sympathized with the Turkish nationalist party MHP (Turkije Informatie 1977a). At the same time HTIB was opposed by smaller Maoist groups who viewed both the TKP and HTIB as representatives of 'social fascism'.

Between 1975 and 1979 HTIB evolved into a national umbrella organisation with different branches in the Netherlands. The organisation also established close ties with Turkish organisations in other European countries that supported the Turkish communist party TKP. ${ }^{3}$ HTIB also acceded to the Federation of Turkish Workers Associations in West Germany, FIDEF. ${ }^{4}$

The establishment of TKP headquarters in Germany and the arrival of TKP leaders in the Netherlands reveal how Moscow-oriented organisations were influenced from abroad. TKP influence on HTIB now rose enormously. TKP leaders became members of HTIBB and in 1982 established a committee for the defence of human rights in Turkey (NTKVMD) which sought to put international pressure on the Turkish junta. Their activities included lobbying the Dutch parliament and human rights organisations such as Amnesty International. At the same time, its members tried 'to recruit TKP members, who eventually would return to Turkey and start a revolution'.5 It was, however, difficult to continue the party's work from abroad. As a former TKP member in exile explains: 'our cadre in Turkey were being tortured or were in hiding. It was extremely difficult to remain in contact.' 6

Although TKP adherence was prominent among HTIB members, it is important to note that the Moscow-oriented TKP was not the only party with which they sympathised. For example, the present chairman of HTIB, a member of the TKP in the Netherlands in the 1980s, was active in the Albania-oriented Maoist party Dev Yol when living in Turkey. One member of the TKP administrative board who continued her activities within HTIB was previously active in the workers party TIP and the Kurdish workers party PKK. Dev Yol adherents were to be found in Turkish workers organisations throughout the Netherlands, not only within HTIB. In the mid1980s, TKP members within HTİB tried to work together with exiles from other

3 HTIB archive International Institute for Social History (IISH), Amsterdam: http://www.iisg.nl/archives/en/files/h/10751062.php, accessed in May 2005.

4 The FIDEF brought together organisations in Europe that sympathized with the Turkish Kemalist party, CHP, and the confederation of socialist trade unions, DİSK. In those days DİSK attracted CHP as well as TKP followers. Turkije Informatie (1978) Regeringswisseling, Turkije Informatie. On the FIDEF inauguration congress representatives of DISK and the CHP held speeches. The highlight of the event was a taped speech of the CHP leader Ecevit. Turkije Infomatie (1977) Verkiezingen en geweld. Vervolg dossier Grijze wolven, Turkije Informatie.

5 Interview with HTIBB chairman and former member of Dev Yol and the TKP, Amsterdam, 19 October 2004.

6 Interview with former TİP, TKP, DİSK, PKK, HTİB and HTKB member, Istanbul, 19 January 2004. 
political movements (see also Turkije Informatie, 1978). An umbrella organisation in exile was created in 1986, made up of individuals from the TKP, Dev Yol, PKK, and the workers parties TSIP and TIP. Due to internal and ideological conflicts, however, it quickly dissolved. ${ }^{7}$ Despite the ideological and personal conflicts, involvement in Turkish movements in exile became the basis for long-term friendships, as will be seen in the next section.

Only a year later, in 1987, the TKP at a meeting in Brussels merged with the Worker's Party of Turkey (TIP) to become the United Communist Party of Turkey (TBKP). Although the penal code still made communist politics illegal in Turkey, Prime Minister Özel hinted that restrictions might be lifted. The leaders of the TBKP returned to Turkey on 11 November and were jailed upon arrival (Zürcher, 2004: 284285).

The TKP dissolved in 1989 after the fall of the Berlin wall. ${ }^{8}$ Internal TKP conflicts over the merger with TIP heavily influenced HTIB in the Netherlands, whose members were mainly comprised of first generation labour migrants attached to the TKP. When the TKP merged with the TIP, many members left the organisation. ${ }^{9}$ Dev Yol-affiliated organisations in Germany also began to redirect their efforts towards migrant issues (Özcan, 1992).

Around the same period, HTIB concluded that the 'temporary' stay of Turkish labour migrants in the Netherlands had become permanent. The organisation accordingly redirected the focus of its activities from Turkey to the Netherlands (Van den Meerendonk and Tilburg, 1988). HTİB thus began to cooperate with Turkish organisations of different political colours through the IOT, the Consultative Council of Turks of the Dutch government. IOT represents a variety of Turkish migrant federations that, like HTIB, are rooted in the turbulent 1970s. Although the various groups have clashed in the past and their previous political orientations remain visible, their common position as Turkish migrants in the Netherlands brings them together in the IOT. To prevent conflict based on ideological differences, IOT members do not discuss Turkish politics during meetings.

\section{Pro-Albanian organisations: the foundation of DİDF}

Before the 1980 coup, a small but militant group following Albanian communism was active in the Netherlands (its European headquarters was in Germany). With the arrival of Revolutionary Communist Party of Turkey (TDKP) cadre in the Netherlands after the 1980 coup, the federation DIDF was founded in 1985 (Van Zuthum, 1994: 24; Den Exter and Hessels, 2003: 11). Its independent sister

7 Ibid.

8 Interview with HTİB chairman and former member of Dev Yol and the TKP, Amsterdam, 19 October 2004.

9 HTIB archive International Institute for Social History (IISH), Amsterdam: http://www.iisg.nl/archives/en/files/h/10751062.php, accessed in May 2005. 
organisation in Germany had existed since 1980 (see also Özcan, 1992: 261-264). The official aim of DIDDF in Germany was twofold: to represent the interests of Turkish workers and to support the reinstallation of democracy in Turkey. In practice, it mainly organised activities against the junta in Turkey.

Although political refugees affiliated with the TDKP established the DIDF, the former's influence on the latter remains unclear. Together with radical Dutch antiracism organisations, DIDF since its foundation has championed full equality for foreigners. With respect to Turkey, DİDF has supported repressed groups and individuals, mainly Kurds (Van Zuthum, 1994: 24); the organisation pleads for the Kurdish right to self-determination and the acknowledgement of Kurdish rights in Turkey. ${ }^{10}$ Likewise, one of its goals in the Netherlands is to contribute to full equality and participation of all people from Turkey (De Voogd and Van der Meulen, 2002). DIDF argues that the Turkish immigrant community is (ethnically) divided through the interference of the Turkish government via its consulates; it further criticises the Dutch government for directing policies towards 'ethnic' Turks and not for people from Turkey, thereby excluding Kurds from full participation. This is one reason why DIDF (as opposed to HTIB) is not a member of the Consultative Council of Turks in the Netherlands, IOT.

\section{TRANSNATIONAL PARTY POLITICS OF THE LEGAL TURKISH LEFT SINCE THE 1990S}

Since the late 1980s HTIB and DIDF have concentrated their activities on the position of Turkish migrants in the Netherlands. Both have become active in immigrant politics, while their members have started to represent Dutch parties in local politics. ${ }^{11}$ But while HTIB has abandoned its mission towards Turkey, DİDF has not. How does the HTIB's sole focus on the Netherlands and the DIDF's focus on both Turkey and the Netherlands influence their transnational ties with groups in Turkey?

Presently, individual HTİB members maintain good relations with members and leaders of the legal left parties founded in the late 1990s such as the new TKP (no extension of the old TKP) and other small socialist parties founded in the early 1990s, such as DSIP. The transnational contacts are personal in nature - continuations of friendships established during past involvement within the TKP and Dev Yol, while still living in Turkey or in exile in the Netherlands. Some TKP and DSIP cadre lived in exile in the Netherlands for several years, and after their return to Turkey founded or joined these new parties. ${ }^{12}$

10 Interview with DİDF chairman, Amsterdam, 15 July 2004.

11 Interview with HTIB chairman and former member of Dev Yol and the TKP, Amsterdam, 19 October 2004.

12 Ibid. 
As noted in the previous section, HTIB also harboured people who were (also) or used to be members of Dev Yol. As in Turkey, many former Dev Yol cadre in the Netherlands regrouped into the left socialist party ÖDP. In 1997, one year after the foundation of ÖDP in Turkey, a former Dev Yol exile and ex-HTİB chairman founded the ÖDP solidarity committee - ÖDK - in the Netherlands. ${ }^{13}$ Though founded by a former HTİB leader, ÖDK has no ties with that organisation. Instead ÖDK regrouped former Dev Yol adherents in the Netherlands, who were previously spread over several Turkish workers organisations. ÖDK in the Netherlands has 132 members who pay contributions to the mother party and around 500 sympathizers. In Germany this number lies somewhere between 800 and 1,000. ${ }^{14}$ ÖDK further has a European umbrella - ÖDK Europe - that unites branches in the Netherlands, France, Belgium, England, Germany, Austria and Switzerland. Every six months they meet to discuss problems of Turks residing in Europe. Their findings are reported to the mother party in Turkey to advise it on specific issues relating to Turks living in Europe. In addition ÖDK takes part in party congresses. ÖDP claims that the input of ÖDK members broadens the vision of the party as many individuals are active in political parties in Europe; their skills and political experience are highly valued. ${ }^{15}$ The ÖDK chairman in the Netherlands, for instance, is a municipal councillor for the Dutch Green Party in Amsterdam. In addition, the ÖDK financially supports the pro-ÖDP newspaper Birgün. Although the daily is available only in Turkey, ÖDK members contribute articles and weekly columns. ${ }^{16}$

Furthermore, ÖDP receives electoral support from ÖDK Europe. In 2003, ÖDP leaders toured in Europe to ask for assistance in campaigning for the 2004 local elections. ${ }^{17}$ In response, ÖDK members organised trips to Bahadin (Yozgat province, Central Anatolian Region) and Hopa (Artvin province, Black Sea Region). They arrived in cars with Dutch plates to show they had come all the way from the Netherlands in support. ${ }^{18}$ Those with Turkish passports voted. Those who stayed in Europe contacted their friends and relatives in Turkey and advised them to vote for ÖDP. ${ }^{19}$ The ÖDP in Turkey also entered the 2004 local elections under the banner of the social democratic party SHP. While the alliance united small parties like EMEP, the Kurdish party DEHAP, ÖDP and the social democratic SDP, it proved difficult for organisations that supported these parties to campaign together in the Netherlands.

13 Interview with ÖDK NL chairman and former Dev Yol activist and HTİB chairman, Amsterdam, 6 October 2004.

14 Ibid.

15 Interview with ÖDP co- founder and member of the party assembly, Ankara, 11 November 2004.

16 Interview with ÖDK NL chairman, Amsterdam, 6 October 2004 and interview with ÖDP cofounder and member of the party assembly, Ankara, 11 November 2004.

17 Notes of meetings of ÖDP Europe: 4-5 January 2003, 8-9 May 2004 in Basel, Switzerland; 15-16 November 2003 in Paris, France; 31 January-1 February 2004 in Mainz, Germany. Received by email from ÖDP co-founder and member of the party assembly, November 2004.

18 Interview with ÖDK NL chairman, Amsterdam, 6 October 2004.

19 Interview with ÖDP co-founder and member of the party assembly, Ankara, 11 November 2004. 
Following the 1999 local elections the ÖDP won the mayoralties of Geçit (Erzincan province) and Agilbasi (Malatya province) in the East Anatolian Region. After the 2004 municipal elections they lost their local power but gained mayoralties in Hopa (Artvin province) in the Black Sea Region and in Bahadin (Yozgat province) in the Central Anatolian Region. The ÖDP wants to make these villages exemplary, and towards this end ÖDK Europe sends money and material goods. Especially Bahadin is an interesting case. A typical emigration village, temporary returnees from Europe or large Turkish cities swell its population from 500 in winter to 3,200 in summer. ${ }^{20}$ The ÖDP mayor himself is a return migrant from Germany whose election campaign was coordinated by the 'Bahadin hemşeri organisations' in Europe and Turkey. These organisations, which refer to common local origin, were established in the mid-1980s. In fact they channelled Dev Yol politics, since the outlawed movement could not openly exist. Today these organisations are used to facilitate ÖDP politics in Bahadin. ${ }^{21}$

Why is a small party like ÖDP so well-organised in Western Europe? Much of the explanation lies in the previous involvement of its European followers in the illegal, Albania-oriented Maoist party Dev Yol. Connected via dense networks, former Dev Yol supporters over the years established numerous organisations that now form the basis of the European branch of ÖDP. Many ÖDP members have lived in exile in Western Europe, and maintain contacts with fellow party members who opted to settle in Europe permanently. And with the prominence of returnees in the party, the ÖDP supports policies that favour Turks living abroad.

Thus contacts of present HTİB members with Turkish political parties continued on a personal level, with former Dev Yol cadre creating an official solidarity committee for the ÖDP. Although there is insufficient information to compare past and present contacts with political parties of the formerly Albanian oriented federation, DIDF, the latter's transnational trajectory clearly differs from that of HTIB and former Dev Yol cadre. Reflecting developments in Turkey, individual members of DIDF now support EMEP (both this Turkish party and DIDF were founded by former TDKP cadre). Although DİDF has no formal ties with EMEP, its members maintain regular contact with the party in Turkey, with the DIDDF's chairman visiting EMEP congresses in Turkey and EMEP's leader regularly lecturing at DIDF gatherings. ${ }^{22}$ Both EMEP and DIDF have similar stances on Turkish politics and Turkish migrants in Europe, for instance on the desirability of Turkish workers to fully participate in political parties and trade unions in the Netherlands ${ }^{23}$, and on the position of Kurds (in both Turkey and the Netherlands). This is explicitly reflected in DIDF being an organisation for migrants from Turkey, rather than one for ethnic Turks.

20 Interview with the coordinator of Bahadin committees in Europe and Turkey, advisor of mayor of Bahadin and former Dev Yol activist, Ankara, 11 November 2004.

21 Ibid.

22 Interview with DIDDF chairman, Amsterdam, 15 July 2004.

23 Interview with EMEP chairman, Istanbul, 13 February 2005. 
More importantly, DIDF supported EMEP in the national elections of 2002 and in local elections two years later. EMEP entered the 2002 elections under the banner of the Kurdish party DEHAP. Together with the Kurdish Federation FED-KOM, DIDF founded a DEHAP solidarity committee in the Netherlands. Together they organised a one-day voting trip to Istanbul (Ülger, 2002: 10). In total ten airplanes were charted for DEHAP voters in Europe (ANP, 2002). Most supporters simply cast their ballots, while others helped in fundraising and campaigning. ${ }^{24}$ In the Netherlands DIDF and FED-KOM organised a meeting during the election campaign to underline Turkish and Kurdish fraternity, while the leader of EMEP was invited for another joint meeting. ${ }^{25}$ EMEP and DEHAP entered the 2004 local elections in coalition with and under the name of the Social Democratic People's Party, the SHP. DIDF did not urge its members to vote, but said: 'If you happen to go and if you still have a right to vote, vote for SHP. If you have relatives who are in doubt, advise them to vote for SHP. ${ }^{26}$ Finally, DİDF supports the pro-EMEP Turkish newspaper Evrensel, especially its European edition, with articles. ${ }^{27}$

This section has traced the development of the transnational political ties of Turkish workers' organisations in the Netherlands such as HTIB and DIDF after the revolutionary parties they sympathized with lost importance or became the basis for new legal political parties in Turkey. It further illustrated how former Dev Yol cadre in the Netherlands - the group that took to the streets in Turkey to fight right-wing movements in the 1970 s - remained loyal to the movement by establishing an official branch of the Turkish party that has its own roots in Dev Yol. HTIB's sole focus on the position of migrants in the Netherlands and DIDF's aim of promoting change in Turkey is reflected in the development of their relations with Turkish political parties. While the ties of both organisations with Turkish political parties have weakened, they have also evolved quite differently. HTİB's transnational political contacts have become personal in nature, while those of DİDF remain (though not formally) on an organisational level.

\section{REPRESENTATION OF THE ILLEGAL TURKISH LEFT IN THE NETHERLANDS SINCE THE 1990S}

The strategies of leftwing parties established in the 1990s that remain illegal in Turkey are similar to those seen in the 1970s and 1980s. Leaders reside in exile in European countries, where they more or less freely continue their activities. They have created party branches in European cities, connected through dense networks, and have become active in migrant politics and organisations. They try to pressure the Turkish

24 Interview with DEHAP Vice-President, Ankara 10 December 2004.

25 Interview with DİDF chairman, Amsterdam, 15 July 2004.

26 Ibid.

27 Interview with a journalist of Evrensel, Istanbul, 9 August 2003 and with DİDF chairman, Amsterdam, 15 July 2004. 
state by lobbying national governments and European institutions. This section traces the activities of the two most important groups, DHKP/C and MLKP.

As figure 1 shows, DHKP/C originates in Dev Yol but broke away a year after its founding to establish DHKP/C's forerunner Dev Sol. Although Dev Sol activists were clearly represented in the Netherlands and Europe in the 1970s and 1980s - they had their own bulletin - it is unclear whether they were represented in any Turkish organisation. Studies on Germany show that Dev Yol headquarters publicly distanced itself from Dev Sol (Özcan, 1992).

Regarding the forerunners (TKP/ML) of the MLKP, we only know that adherents founded a federation in Germany in 1977. We do not know where and how they were represented in the Netherlands. The reason for this gap in the data stems from the illegality of these parties in Turkey itself. In $2000 \mathrm{DHKP} / \mathrm{C}$ was put on the list of European terrorist organisations, though it was only outlawed in Germany and the UK. This meant that it was difficult to find representatives in the Netherlands. When I did, they were quite reluctant to talk. Thus in addition to the more conversation-like interviews I had with sympathizers of these two parties, I used secondary material including their pamphlets, websites, publications, newspaper articles and went (with them) to demonstrations to conduct participant observation. For security reasons I did not search for these groups in Turkey, as I did for the other parties. The analysis of their strategies begins around their foundation in the mid-1990s when they chose to continue an illegal revolutionary course.

In the Netherlands DHKP/C sympathizers follow a peaceful path; several dozen are actively involved in the party (AIVD, 2004: 26). A branch of the party was located in Amsterdam between 1995 and 2003 but has since moved to Brussels. ${ }^{28}$ Nevertheless, DHKP/C followers openly show their affiliation with the party. On 1 May 2005 they marched through the city of Rotterdam carrying flags of the party. ${ }^{29}$ DHKP International, headquartered in Brussels, celebrated the anniversary of the party in the Netherlands in 2002 and 2005, where they commemorated their revolutionary martyrs including THKP founder Mahir Cayan. ${ }^{30}$ The music group GrupYorum often performs during these celebrations. In its political songs, the band criticizes the Turkish state and expresses its solidarity with leftwing political activists and prisoners. Because the Turkish state considers Grup Yorum a part of DHKP/C, some musicians have been imprisoned while others have found refuge in Europe. ${ }^{31}$ News and books on activities of the DHKP/C are published by Press Agency Özgürlük in Amsterdam.

Despite the DHKP/C being legal in the Netherlands, the Dutch government cooperated in an international police raid against potential DHKP/C-affiliated organisations in 2004. In response DHKP/C members participated in what they called

28 Interview with a spokesman of Press Agency Özgürlük, Amsterdam 17 September 2004.

29 http://www.dhkc.info/668.0.html, accessed on 4 May 2006.

30 http://www.dhkc.info/DHKC_International.435+M5682345ee0c.0.html and http://www.dhkc.net, accessed on 14 April 2006.

31 Interview with Grup Yorum representative, Istanbul, 8 January 2005. 
the 'International Platform Against Isolation' in Brussels, mobilizing European lawyers and human rights advocates to observe the trials of $\mathrm{DHKP} / \mathrm{C}$ activists in Istanbul later that year. ${ }^{32}$

Some DHKP/C sympathizers are active in the Anatolian Cultural Centre, a Turkish migrant organisation in Rotterdam. Besides offering regular cultural activities, it organises and funds meetings about socialism for youths in Turkey. ${ }^{33}$ The centre itself is not formally linked to the party; its sympathies, however, are obvious. At the building's entrance is a corner with photos dedicated to the 'martyrs' of the armed wing in Tokat (Black Sea Region). The Centre also holds memorial meetings for friends and family of organisational members who have died fighting the Turkish army. ${ }^{34}$

In the Netherlands, DHKP/C is organised around the Dutch branch of the Association for the Support of the Families of Prisoners, TAYAD. The Dutch branch of TAYAD raises funds for the organisation in Turkey ${ }^{35}$ and attempts to influence the Dutch government by writing letters to parliament. ${ }^{36}$ DHKP/C adherents in the Netherlands have further organised hunger strikes in solidarity with the Death Fast Resistance in Turkish prisons. ${ }^{37}$ In 2000 a hunger strike in Rotterdam was dramatically interrupted when one of the participants was killed by Turkish nationalists. The relationship between TAYAD and DHKP/C became very visible during a demonstration of the European TAYAD branches in Brussels in $2004 .{ }^{38}$ This demonstration in solidarity with the Death Fast Resistance was attended by DHKP/C members in exile, representatives of the International DHKP/C headquarter in Brussels, and the Anatolian Cultural Centre. The demonstrators protested in front of the European parliament and the Turkish embassy holding photos of hunger strikers who had died in Turkey while shouting the names of DHKP/C 'martyrs'.

The MLKP in the Netherlands is even smaller than the DHKP/C. It is made up of a tiny group of sympathisers involved in non-violent actions such as participating in Dutch leftwing demonstrations (AIVD, 2005: 23). In their European magazine journal the party publishes solidarity statements for the 'martyred' members of their armed wing in Turkey (MLKP, 2005). MLKP members are also organised in the cultural organisation VEKSAV, linked to the cultural magazine Hayat ve Sanat (Life and Art) in Turkey and its European federation in Germany. VEKSAV organises politically-loaded cultural activities. ${ }^{39}$ On the European level VEKSAV participates in the European Confederation of Oppressed Immigrants, AVEG-Kon, which organises protests against globalisation, discrimination and the expulsion of political refugees who supported the Death Fast Resistance in Turkey, in which MLKP and DHKP/C prisoners participated. ${ }^{40}$

32 Personal communication with delegate from the UK at TAYAD demonstration in Brussels, 21 October 2004.

33 Interview with a volunteer for the Anadolu Kultur Merkezi, Rotterdam, 6 October 2004.

34 Ibid.

35 Interview with a spokesman of Press Agency Özgürlük, Amsterdam 17 September 2004.

36 Press Release 'Tayad stuurt brief naar Tweede Kamer', TAYAD Komite, 13 November 2001.

37 Interview with a volunteer of the Anadolu Kultur Merkezi, Rotterdam, 6 October 2004.

38 Observations of the author during TAYAD demonstration in Brussels, 21 October 2004.

39 Hayat ve Sanat invitation, Den Haag, 8 October 2005.

40 See also http://thecaravan.org/files/caravan/Berber_de.pdf, accessed in May 2006. 
Interestingly, the branches and members of the illegal parties mentioned in this section and the representatives and sympathizers of the legal Turkish parties all participate in the Dutch demonstration platform Keer het Tij. This platform - which unites roughly 500 leftwing organisations and parties - was founded in 2002, a response to the more conservative Dutch government that came to power that year. Sympathizers, members and branches of Turkish leftwing parties - the illegal parties MLKP, TKP/ML, TKIP and DHKP/C; the migrant organisations DIDDF, HTIB and the Anatolian Cultural Centre; the branch ÖDK and the Turkish NGO TAYAD - were all present at a Keer het Tij demonstration in $2005 .{ }^{41}$ In their struggle for (what they consider) social justice, they have found common ground in protest movements in the Netherlands.

\section{CONCLUSION}

To return to the central question of this paper: how can the different trajectories of transnationally active migrant organisations with a shared political orientation - in this case the radical left - be explained? The key explanatory factors revealed by existing scholarship are migration motives, political opportunities in the receiving country and the country of origin, and length of stay. These factors - while also applicable to the Turkish radical left in the Netherlands - need to be sharpened.

As shown in this paper, changes in opportunities for the left in Turkey influenced ties with migrant organisations in the Netherlands. In the 1970s and 1980s the Turkish left as a whole was formally excluded from political participation in Turkey. Leftwing political movements continued their activities in Turkish labour organisations and branches in exile, connected through dense European networks. Their activities, networks and strategies clearly reflected the specific context in which their sister organisations in Turkey operated.

With relative political stability in Turkey in the 1990s, some radical left groups became legal parties. This influenced Turkish migrant organisations abroad: organisations that had sympathized with previously illegal movements in Turkey shifted the focus of their activities to the country of settlement. They not only realized most members would stay in the Netherlands permanently (as happened with other organisations); the shift was also due to the legalization of their sister movements in Turkey. Coordination from abroad was no longer necessary.

Although migrant organisations maintained contacts with these newly-founded political parties, their transnational contacts differed substantially. Organisations that completely lost their mission towards Turkey only maintained contacts on a personal level. Where at least some homeland-directed purpose remained, more formal

41 Observations of the author at Keer het Tij demonstration, The Hague, 24 September 2005. See also the list of member organisations at: http://www.keerhettij.nl/organisaties.htm, accessed in April 2007. 
organisational contacts were kept alive. Finally, we see that the transnational contacts of Turkish parties founded by exiles who returned to Turkey are more likely to exist on an organisational level.

The importance of organisational developments in the homeland for transnational politics becomes clear when this experience is contrasted with that of organisations that sympathized with Turkish parties and movements that remained illegal after 1990. The path of newly-founded illegal parties has echoed those of illegal movements in the 1970 s and 1980 s. They continue to politicize immigrant organisations - no longer those of temporary labour migrants, but the cultural organisations of permanent migrants. And like exiles in the past, their European networks are crucial as they lobby for the protection of the rights of their members in Turkey at national and European levels.

Current ties between migrants and/or organisations and legal Turkish parties are mainly used to provide electoral support. Migrants only seem to have a voice in party matters and policy when the majority of the administrative board in Turkey has a migrant history as well. On the other hand, ties with illegal parties that continue to exist are still vital for the existence of these parties and their leaderships.

What this shows is that transnational politics are not only a question of activities or loyalties that transcend national borders. The organisational networks that allow loyalties to be translated into activities are likewise transnational. What happens at the organisational nodes in the country of origin is thus often crucial for developments in the country of settlement. Indeed, many groups that are often seen unproblematically as migrant organisations have only become true migrant organisations after their sister organisations in the homeland chose a political path that made support from abroad obsolete. In this way, homeland politics cast an even longer shadow over transnational politics than is often acknowledged.

Whatever trajectory leftwing Turkish organisations in the Netherlands have chosen over time, there is no indication that maintaining an interest in homeland politics today hinders integration in the Netherlands or threatens Dutch democracy. On the contrary - despite differences in ideology, whether supportive of legal or illegal parties in Turkey, or without organisational ties to Turkey at all - all groups under study participate in the same Dutch protest platform. This is a sign of integration in and of itself, since they are demonstrating - sometimes under the banner of a Turkish political party - to improve their position in the Netherlands. It could even be argued that previous and present involvement in homeland politics reinforces participation in the political arena of the country of settlement.

To conclude, these findings suggest that we need to specify homeland-related factors that determine transnational political practices in the country of settlement. Instead of assuming that homeland 'political opportunities' similarly affect all groups, we need to ask how specific groups - even within a comparable political stream - are included or excluded from homeland political participation. Only then will we be able to explain how and why migrant organisations continue homeland-directed activities, redirect their interests to the country of settlement, or combine elements of both. 


\section{References}

AHMAD Feroz (1993) The making of modern Turkey, London/New York, Routledge.

AIVD, ALGEMENE INLICHTINGEN- EN VEILIGHEIDSDIENST (2004) Jaarverslag 2003, Den Haag, Minsterie van Binnenlandse Zaken en Koninkrijksrelaties.

AIVD, ALGEMENE INLICHTINGEN- EN VEILIGHEIDSDIENST (2005) Jaarverslag 2004, Den Haag, Ministerie van Binnenlandse Zaken en Koninkrijksrelaties.

AL-ALI Nadje, BLACK Richard and KOSER Khalid (2001) Refugees and transnationalism: the experience of Bosnians and Eritreans in Europe, Journal of Ethnic and Migration Studies, 27 (4), pp. 615-634.

ANDERSON Patrick (2004) 'To Lie Down to Death for Days.' The Turkish Hungerstrike, 20002003, Cultural Studies, 18 (6), pp. 816-846.

ARGUN Betigül Ercan (2003) Turkey in Germany. The Transnational Sphere of Deutchkei, London, Routledge.

BAKKER René, VERVLOET Luc and GAILLY Anton (2002) Geschiedenis van Turkije, Amsterdam, Bulaaq.

BAYKAN Barış Gençer and LELANDAIS Gülçin Erdi (2004) Cross-readings of the antiglobalisation movement in Turkey and beyond. Political culture in the making, ISSJ UNESCO, (182), pp. 519-528.

CAN Murat and CAN-ENGIN Hatice (1997) De zwarte tulp. De positie van Turken in Nederland, Utrecht, Uitgeverij Jan van Arkel.

ÇINAR Alev and ARIKAN Burak (2002) The Nationalist Action Party: Representing the State, the Nation or the Nationalists?, in Barry RUBIN and Metin HEPER Eds., Political Parties in Turkey, London, Cass, pp. 25-40.

DHKC (1998) Political Development in Turkey: The People on the Road to Power, London, DHKC Information Bureau.

DHKC (1998) We Are Right. We Will Win, London, DHKC Information Bureau.

DHKP (1995) Het program van de revolutionaire volksbevrijdingspartij, Amsterdam, Halk Kurtulus Uitgeverij.

ESBROECK A. Van (1979) Grijze Wolven. Wat zijn dat?, Nijmegen, A. van Esbroeck Nijmegen.

EXTER JAK Den and HESSELS T. (2003) Organisaties van minderheden, in J.E. OverdijkFrancis et al. Ed., Handboek minderheden, Houten, Bohn Stafleu Van Loghum, pp. 7/1050-134.

FONER Nancy (2001) Transnationalism Then and Now: New York Immigrants Today and at the Turn of the Twentieth Century, in Héctor R. CORDERO-GUZMÁN, Robert C. SMITH and Ramón GROSFOGUEL Eds., Migration, Transnationalization, \& Race in a Changing New York, Phiadelphia, Temple University Press, pp. 35-57.

GEERSE Mirjam (1998) Turkse idealen op Nederlandse bodem. Een kwalitatief onderzoek onder ülkücü's ('idealisten') in Nederland, Utrecht, Doctoraal scriptie Vakgroep Culturele Antropologie. Faculteit der Sociale Wetenschappen. Universiteit Utrecht.

GUARNIZO Luis Eduardo, PORTES Alejandro and HALLER William (2003) Assimilation and Transnationalism. Determinants of Transnational Political Action among Contemporary Migrants, American Journal of Sociology, 108 (6), pp. 1211-48.

GÜNES-AYATA Ayşe (2002) The Republican People's Party, in Barry RUBIN and Metin HEPER Eds., Political Parties in Turkey, London, Frank Cass, pp. 102-121.

HALK KURTULUS (1997) Konterguerilla. Der Name Des Krieges Gegen Das Volk, Amsterdam, Halk Kurtulus Uitgeverij.

KOOPMANS Ruud, STATHAM Paul, GIUGNI Marco and PASSY Florence (2005) Contested Citizenship. Immigration and Cultural Diversity in Europe, Minneapolis, University of Minnesota Press. 
KOOPMANS Ruud and STATHAM Paul (2003) How national citizenship shapes transnationalism: A comparative analysis of migrant claims-making in Germany, Great Britain and the Netherlands, in Christian JOPPKE and Ewa MOROWSKA Eds., Toward Assimilation and Citizenship. Immigrants in Liberal Nation-States, New York, Palgrave Macmillan, pp. 195-238.

KULAKSIZ Ahmet (2003) Two Sisters' Lives. Canan and Zehra, Amsterdam, Ozgurluk Publishing. LANDAU Jacob M. (1981) Pan-Turkism in Turkey. A Study of Irredentism, London, C. Hurst \& Company.

LANDAU Jacob M. (1974) Radical Politics in Modern Turkey, Leiden, Brill.

LIPOVSKY Igor P. (1992) The Socialist Movement in Turkey 1960-1980, Leiden, Brill.

MCDOWALL David (1996) A Modern history of the Kurds, London, I.B.Tauris.

MEERENDONK H. Van Den and TILBURG P. (1988) Evaluatierapport van de HTIB, Tilburg, Instituut voor ontwikkelingsvraagstukken KUB Tilburg.

MILLER Mark J. (1981) Foreign Workers in Western Europe. An Emerging Political Force, New York, Praeger Publishers.

MLKP (2005) MLKP Internationales Bulletin.

MOROWSKA Ewa (2003) Immigrant Transnationalism and Assimilation: A Variety of Combinations and the Analytic Strategy it Suggests, in Christian JOPPKE and Ewa MOROWSKA Eds., Toward Assimilation and Citizenship. Immigrants in Liberal NationStates, New York, Palgrave Macmillan, pp. 133-176.

ÖGELMAN Nedim (2003) Documenting and Explaining the Persistence of Homeland Politics Among Gemany's Turks, International Migration Review, 37 (1), pp. 163-193.

ÖZCAN Ertekin (1992) Türkische Immigrantenorganisationen in der Bundesrepublik Deutschland, Berlin, Hitit.

ØSTERGAARD-NIELSEN Eva (2003) Transnational Politics. Turks and Kurds in Germany, London/New York, Routledge.

ØSTERGAARD-NIELSEN Eva (2003) International Migration and Sending Countries: Key Issues and Themes, in Eva ØSTERGAARD-NIELSEN Ed., International Migration and Sending Countries. Perceptions, Policies and Transnational Relations, New York, Palgrave Macmillan, pp. 3-30.

PENNINX Rinus (1980) Politiek extremisme onder Turken, Intermediar, 1/2 (Tussen wal en schip), pp. 61-70.

POPE Nicole and POPE Hugh (1997) Turkey Unveiled. Atatürk and After, London, John Murray.

POULTON Hugh (1997) Top Hat Grey Wolf and Crescent, London, Hurst.

RATH Jan (1985) Migranten, de Centrumpartij en de deelraadsverkiezingen van 16 mei 1984 te Rotterdam, Leiden, Rijksuniversiteit Leiden.

TAYAD SOLIDARITY COMMITTEE (2001) The Terror Report of Turkey 1980-2000, Bielefeld, TAYAD Solidarity Committee.

TURKIJE INFORMATIE (1977) Verkiezingen en geweld. Vervolg dossier Grijze wolven, Turkije Informatie.

TURKIJE INFORMATIE (1978) Balans van vier maanden Ecevit, Turkije Informatie.

TURKIJE INFORMATIE (1978) Regeringswisseling, Turkije Informatie.

TURKIJE INFORMATIE (1981) Devrimici Yol. Turkije Informatie, Turkije Informatie, (2).

TURKIJE NIEUWS (1981) Turkije Nieuws.

ÜLGER Mehmet (2002) Met stembiljet het vliegtuig in, Contrast, (34), pp. 10-11.

VOOGD Barend De and Van Der MEULEN Koen (2002) Nuri Karabulut, landelijk voorzitter DIDF: 'Wij zijn voor vrijwillige assimilatie', Grenzeloos, (69), pp. Grenzeloos.org.

ZÜRCHER Eric J. (2004) Turkey. A Modern History. New edition 2004, London, I.B. Tauris \& Co. ZUTHUM H. Van (1994) Plaatselijke Turkse organisaties in Nederland, Den Haag, IOT. 


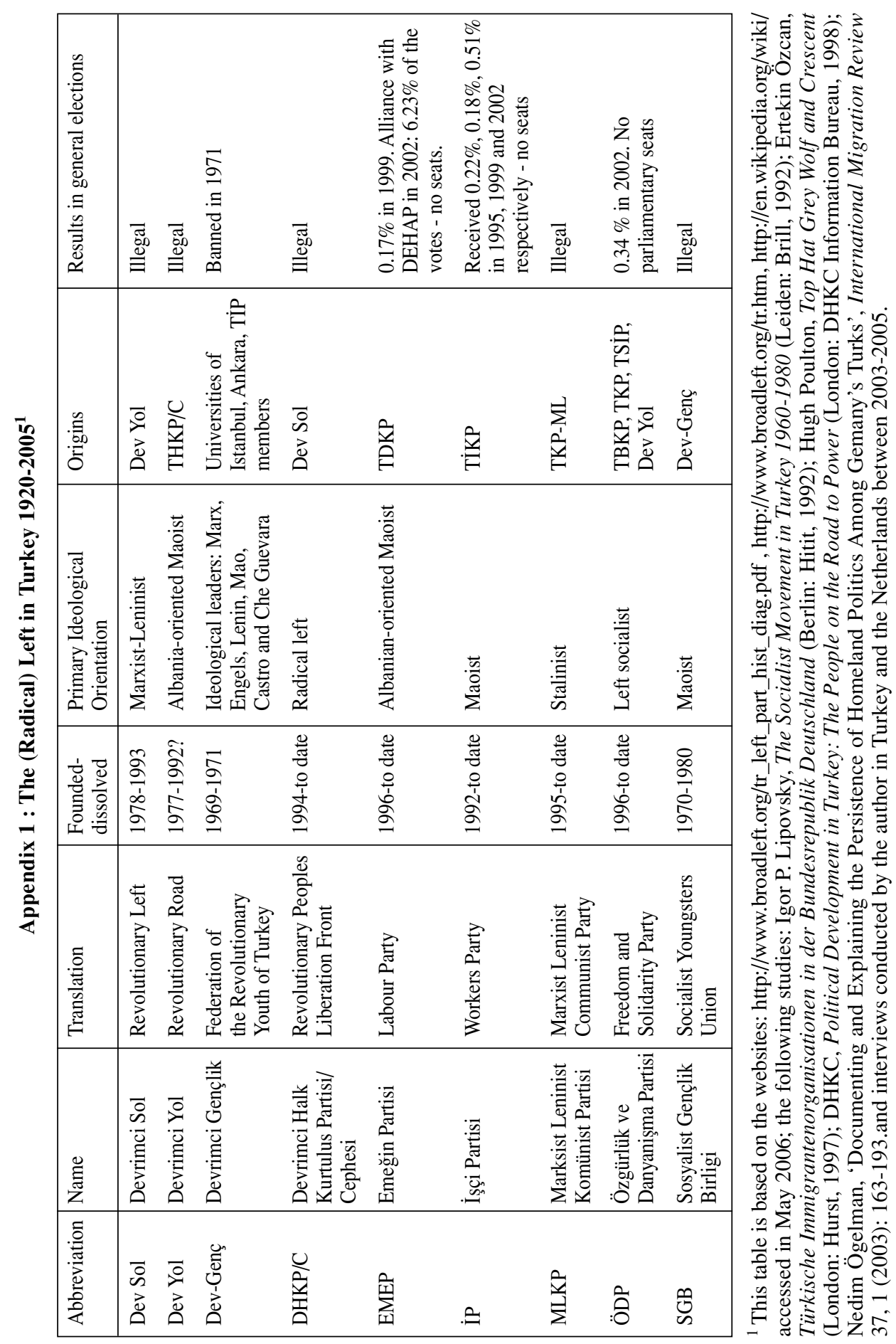




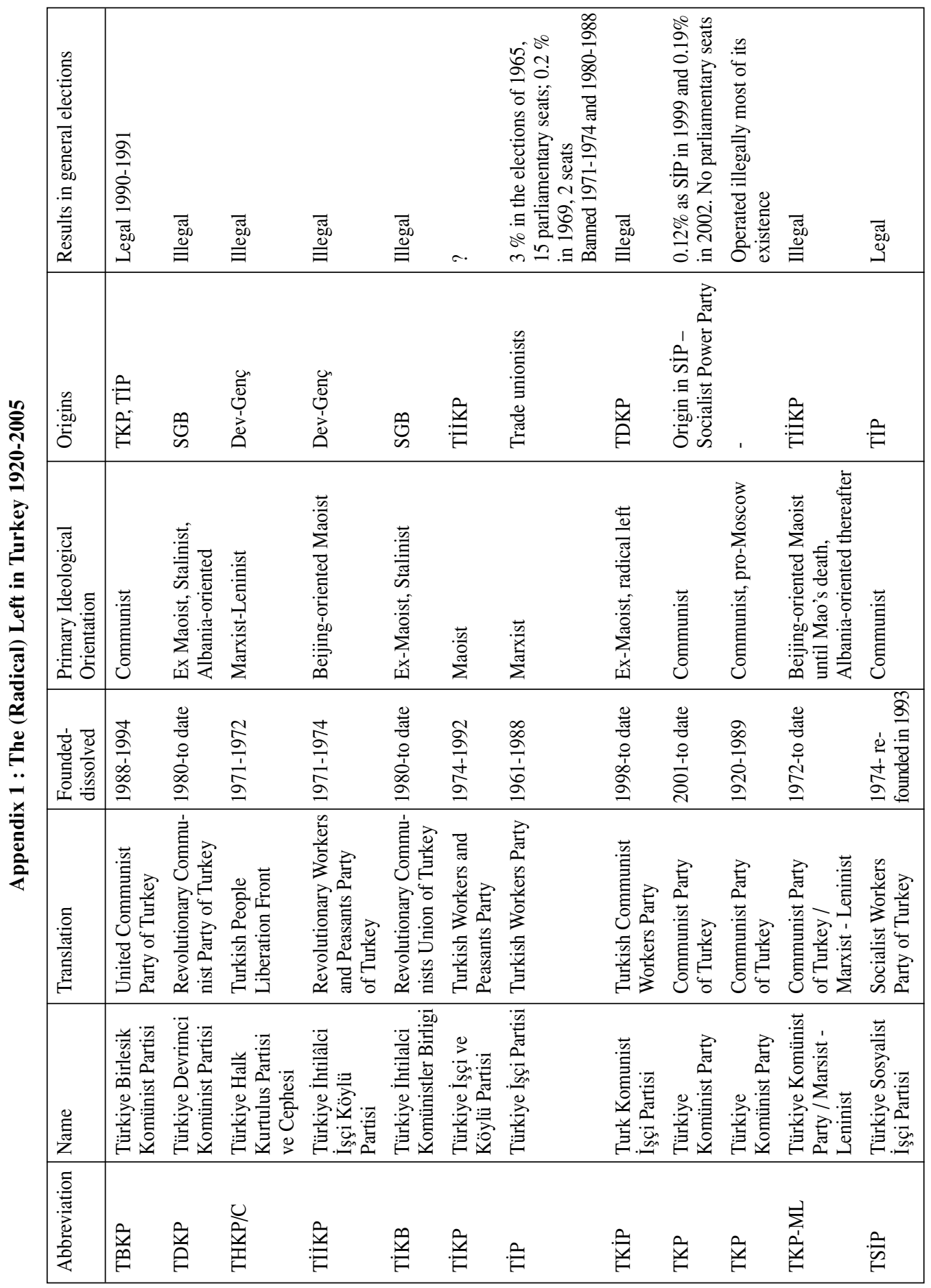


Appendix 2 : List of other mentioned parties and organisations in Turkey and the Netherlands

\begin{tabular}{|c|c|c|}
\hline Abbreviation & Turkish name & English Translation \\
\hline AP & Adalet Partisi & Justice Party \\
\hline ATTF & $\begin{array}{l}\text { Avrupa Türk Toplumcular } \\
\text { Federasyonu }\end{array}$ & $\begin{array}{l}\text { European Federation of Turkish } \\
\text { Socialists }\end{array}$ \\
\hline AVEG-KON & $\begin{array}{l}\text { Avrupa Ezilen Göçmenler } \\
\text { Konfederasoynu }\end{array}$ & $\begin{array}{l}\text { European Confederation of } \\
\text { Oppressed Immigrants }\end{array}$ \\
\hline CHP & Cumhürriyet Halk Partisi & Republican Peoples' Party \\
\hline DEHAP & Demokratik Halk Partisi & Democratic Peoples Party \\
\hline DİDF & $\begin{array}{l}\text { Demokratik İşçi Dernekleri } \\
\text { Federasyonu }\end{array}$ & $\begin{array}{l}\text { Federation of Democratic Workers } \\
\text { Associations }\end{array}$ \\
\hline DİSK & $\begin{array}{l}\text { Türkiye Devrimci İşçi } \\
\text { Sendikalari Konfederasyonu }\end{array}$ & $\begin{array}{l}\text { Confederation of Progressive Trade } \\
\text { Unions of Turkey }\end{array}$ \\
\hline FED-KOM & $\begin{array}{l}\text { Federasyona Komelên Kurd Li } \\
\text { Holland FED-KOM }\end{array}$ & $\begin{array}{l}\text { Federation of Kurdish Associations in } \\
\text { the Netherlands }\end{array}$ \\
\hline FIDEF & $\begin{array}{l}\text { Federal Almanya İşçi Dernekleri } \\
\text { Federasyonu }\end{array}$ & $\begin{array}{l}\text { Federation of Turkish Workers } \\
\text { Associations in the BRD }\end{array}$ \\
\hline НTїB & Hollanda Türkiyeli İsçiler Birliği & Association of Turkish Workers \\
\hline HTKB & Hollanda Türkiyeli Kadınlar Birliği & $\begin{array}{l}\text { Turkish Women Organisation in the } \\
\text { Netherlands }\end{array}$ \\
\hline IOT & Inspraakorgaan Turken & Advisory Board of Turks \\
\hline MHP & Milliyetçi Hareket Partisi & Nationalist Action Party \\
\hline NTKVMD & $\begin{array}{l}\text { Nederlands Turkije Komitee } \\
\text { voor de Verdediging van } \\
\text { Mensenrechten en Demokratie }\end{array}$ & $\begin{array}{l}\text { Dutch Committee for the Defence of } \\
\text { Human Rights and Democracy }\end{array}$ \\
\hline ÖDK & $\begin{array}{l}\text { Özgürlük ve Danyanişma } \\
\text { Koordinasyonu }\end{array}$ & ÖDP Solidarity Committee \\
\hline ÖDK Avrupa & $\begin{array}{l}\text { Özgürlük ve Danyanişma } \\
\text { Koordinasyonu Avrupa }\end{array}$ & ÖDP Solidarity Committee Europe \\
\hline ÖP & Özgurluk Partisi ÖP & Free Party \\
\hline PKK & Partiya Karkari Kurdistan & Kurdistan Workers Party \\
\hline SDP & Sosyal Demokratik Partisi & Social Democratic Party \\
\hline SHP & Soysalistdemokrat Halk Partisi & Social Democrat Peoples Party \\
\hline TAYAD & $\begin{array}{l}\text { Tutuklu Hükümlü Aileri } \\
\text { Yardımlaşma Derneği }\end{array}$ & $\begin{array}{l}\text { Association for the Support of the } \\
\text { Families of Prisoners }\end{array}$ \\
\hline VEKSAV & Vardiya Kültür Sanat Vakfı & $\begin{array}{l}\text { Foundation of the Culture and Art } \\
\text { Vardiya }\end{array}$ \\
\hline
\end{tabular}




\section{L'ombre de la politique du pays d'origine : évolution de la gauche radicale turque aux Pays-Bas}

\section{Liza M. NELL}

Cet article examine l'évolution des liens transnationaux des organisations migrantes avec les partis politiques de la gauche radicale aux Pays-Bas depuis les années soixante-dix. Il montre la diversité des trajectoires des organisations migrantes orientées de manière transnationale : certaines perdent leur caractère radical contrairement à d'autres qui le maintiennent. Nombre de facteurs déterminent, selon la littérature, l'engagement politique transnational : les raisons à l'origine de la migration, la structure des opportunités politiques dans le pays de résidence et dans le pays d'origine et la durée de séjour des migrants. Toutefois ces facteurs ne permettent guère d'expliquer la diversité des trajectoires, puisqu'ils concernent de la même manière toute la gauche turque et, dès lors, ne peuvent rendre compte des différences à l'intérieur de ce courant politique. Les raisons de ces changements sont à chercher ailleurs. L'analyse montre que les organisations migrantes ne deviennent des véritables organisations de migrants que lorsque leur organisation parallèle au pays d'origine a pris une option politique qui ne rend plus nécessaire un soutien de l'étranger. Au lieu de considérer que les opportunités politiques du pays d'origine concernent tous les groupes, l'on doit s'interroger sur la manière, dont certains groupes, appartenant parfois au même courant politique, sont inclus ou exclus de la participation politique dans le pays d'origine. Enfin l'article montre que contrairement à une opinion largement partagée, il n'y a guère d'indications selon lesquelles un intérêt soutenu dans le devenir politique du pays d'origine est un frein à l'intégration politique et constitue une menace pour la démocratie aux Pays-Bas.

\section{The Shadow of Homeland Politics: Understanding the Evolution of the Turkish Radical Left in the Netherlands}

\section{Liza M. NELL}

This article examines evolution of migrants' organisational transnational ties with political parties of the Turkish radical left in the Netherlands since the 1970s. It shows that trajectories of transnationally orientated migrant organisations with a shared political orientation differ substantially from each other. Some lose their radical edge over the years whereas others do not. The factors that existing literature commonly identifies as shaping transnational political involvement - migration motives, political opportunity structures in the receiving country and the (former) homeland, and migrants' length of stay - are insufficient to understand this pattern. They apply to the whole Turkish left in similar measure and therefore cannot account for variation within this political stream. Explanations for the changes in patterns of transnational political ties over time hence need to look further. This article argues that migrant organisations only become true migrant organisations once their sister organisation in the homeland has chosen a political path that has made support from abroad obsolete. Instead of assuming that homeland political opportunities similarly affect all groups, we need to ask how specific groups - even within a comparable political stream - are included or excluded from homeland political participation. Finally, this article shows, that - contrary to what is generally assumed - in this case there is no indication that maintaining interest in homeland politics today hinders political integration or threatens Dutch democracy. 


\section{La sombra de las políticas nacionales : entender la evolución de la izquierda radical turca en los Países Bajos}

\section{Liza M. NELL}

Ese artículo observa la evolución de los lazos transnacionales de las organizaciones migratorias con los partidos políticos de la izquierda radical turca en los Países Bajos desde los años setenta. Muestra que las trayectorias de organizaciones de migrantes con orientación transnacional pueden discrepar fuertemente entre ellas. Algunas pierden su carácter radical con el paso del tiempo mientras otras no. Los factores explicativos del compromiso político transnacional sobresalientes en la literatura - motivos de migración, estructuras de oportunidad política en los países de origen y de acogida, y la duración de la estancia - no son suficientes para entender ese fenómeno. Se aplican de la misma forma a la totalidad de la izquierda turca de suerte que no nos permiten entender las variaciones que ocurren dentro de esa corriente política. Para entender los cambios en las redes políticas transnacionales con el tiempo, hay que buscar otro tipo de esclarecimientos. Mostramos que las organizaciones de migrantes se vuelven verdaderas organizaciones de migrantes una vez que la organización gemela del país de origen escoge una vía política que hace inútil cualquier asistencia de afuera. En vez de asumir que se dan las mismas oportunidades políticas a todos los grupos, debemos preguntarnos como grupos específicos - aunque de la misma corriente política - puedan participar o no a la política en su país de origen. Y, finalmente, mostramos que al revés de lo que se pretende, no tenemos elementos para apoyar la idea que el interés mantenido en la política del país de origen sea un obstáculo a la integración o una amenaza a la democracia holandesa. 


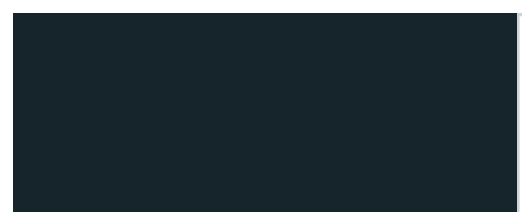

C\&C n70, été 2008

ALTERMONDIALISME(S) OUBLIÉ(S)

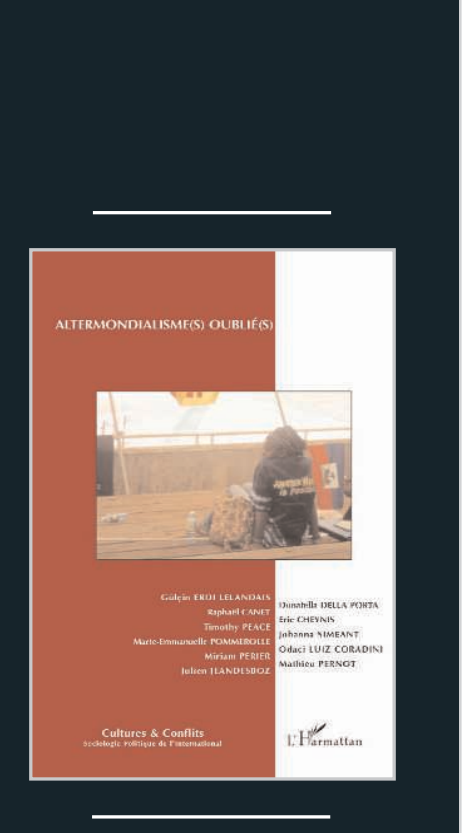

$21 €, 212 \mathrm{p}$.

ISSN : $1157-966 \mathrm{X}$

ISBN : 978-2-296-05909-2

Cultures \& Conflits Sociologie Politique de I'International

Centre d'Etudes sur les conflits

redaction@conflits.org

http://www.conflits.org

\section{Cultures \& Conflits}

Revue de Sociologie Politique de I'International

\section{SOMMAIRE}

Editorial. Altermondialimse(s) oublié(s)

Gülçin ERDI LELANDAIS

L'altermondialisme et la recherche sur les mouvements sociaux.

Quelques réflexions.

Donatella DELLA PORTA

L'intelligence en essaim. Stratégie d'internationalisation des forums sociaux et régionalisation de la contestation mondiale Raphaël CANET

Du printemps ouvrier à l'altermondialisme... Le champ militant et le champ politique en Turquie

Gülçin ERDI LELANDAIS

Trajectoires du Maroc à Porto Alegre. Conditions et logiques de la participation marocaine au Forum social mondial Eric CHEYNIS

L'impact de la "participation musulmane " sur le mouvement altermondialiste en Grande-Bretagne et en France

Timothy PEACE

Voix africaines au Forum social mondial de Nairobi.

Les chemins transnationaux des militantismes africains

Marie-Emmanuelle POMMEROLLE - Johanna SIMEANT

\section{HORS-THEME}

Les participants et les organisateurs du Forum social mondial : la diversité du militantisme Odaci LUIZ CORADINI

\section{REGARDS SUR L'ENTRE-DEUX}

Les enfermés hors-champ. Entretien avec Mathieu Pernot Miriam PERIER - Mathieu PERNOT

\section{CHRONIQUE BIBLIOGRAPHIQUE}

Europe, frontières et politique : chronique autour d'Etienne Balibar Julien JEANDESBOZ

Articles et résumés (français/anglais) en accès libre sur : http://www.conflits.org 